\title{
Western Asia \\ and North Africa in the Neo-Modernity Context
}

Between the Middle East and the Islamic World

\author{
Vassily A. Kuznetsov
}

\begin{abstract}
This article analyzes international relations in Western Asia and North Africa (WANA) amid the ongoing reformatting of the modern world order. The emerging new world order is examined through the transition from post-modernity to neo-modernity. The analysis of theoretical works on post-modernity helps to study the phenomenon of neo-modernity, identify its key features, and compare possible characteristics of the new world order with those of neo-modernity. The second and third parts of the paper explore neo-modernity with regard to WANA. Two options for WANA's political self-identity and two ways to build a regional system of relations are discussed. One of the options suggests looking at WANA from a modern perspective as the Middle East; the other views it as pre-modernistic and part of the Islamic world. The composition of actors, the
\end{abstract}

\footnotetext{
Vassily A. Kuznetsov, PhD in History

Institute of Oriental Studies of the Russian Academy of Sciences, Moscow, Russia

Head of the Center for Arab and Islamic Studies

SPIN-RSCI: 8052-7393

IstinaResearcherID (IRID): 3553785

Scopus AuthorID: 57196044428

E-mail: vasiakuznets@yandex.ru

Address: 12 Rozhdestvenka Str., Moscow 107031, Russia

The article is financially supported by the Russian Science Foundation, project № 17-18-01614 «Problems and Prospects of the International Political Transformation of the Middle East in the Context of Regional and Global Threats».
}

DOI: 10.31278/1810-6374-2019-17-1-124-146 
role of political narratives, the attitude towards borders and sovereignty, the very perception of the underlying principles of the world order are the spheres where the Middle Eastern and Islamic perceptions of international relations contradict each other. Meanwhile, neo-modernity makes possible the parallel existence of these two approaches.

Keywords: Western Asia, North Africa, postmodernity, neo-modernity, Middle East, Islamic world, world order

This article studies the specifics of international relations in the space of Western Asia and North Africa (WANA) in the context of ongoing changes in world politics. The notion of 'space, rather than 'region' or 'territory', is used intentionally. 'Space' is understood as it has been construed by Russian expert N. Kosolapov, who states that "an organized territory becomes a space," that is, "a virtual construct created... for the purpose of arranging perceptions as the basis for and a means of building and reproducing social practices and/or part thereof" (Kosolapov, 2005, p. 3). While assuming that space has some inner structure and certain unity (unlike territory), it may lack political sovereignty as an international-political region. The latter means "a relatively independent subsystem of interstate relations held together mainly by the commonality of certain political problems characteristic of a given region and matching relations" (Gantman, et al., 1984, p. 363; Voskresensky, 2012). Geographically, this is the same territory that is usually defined as the Middle East and North Africa (MENA), or simply the Middle East. In this article the Middle East means a certain concept, while WANA is a more neutral notion that has been used in Russian academic literature before (see, for example: Makhmutov and Mamedov, 2017). The purpose of this study is to analyze the role WANA might play in the emerging new world order and its possible identity as a political space.

This is not a new topic in Middle Eastern studies. In fact, a large number of works are devoted to international relations in WANA and the Middle East's role in the modern system of international relations 
in general. However, most of them focus on current problems in international relations in the region and do not analyze the place of the region in the global system of international relations.

In Russia, the tendency towards studying Middle Eastern issues in relation to global political trends has emerged only recently. In my article, After Postmodernism: Middle Eastern Dimension of One Trend (Kuznetsov, 2017), I outlined some general guidelines for studying correlations between the ongoing changes in the Middle East and global political transformations defined as the end of post-modernity. Those ideas were further considered in a paper co-authored with I. Zvyagelskaya Statehood in the Middle East. The Future Which Started Yesterday (Zvyagelskaya and Kuznetsov, 2017). In her recent followup monograph, The Middle East and Central Asia. Global Trends and Their Regional Realization, Zvyagelskaya compares the impact of global development trends on political processes in the two regions (Zvyagelskaya, 2018). Political scientists V. Naumkin and V. Baranovsky, who wrote the foreword to the collective work, The Middle East in the Changing Global Context, focused on both specific features of global mega trends in the Middle East and on the formation of distinct regional trends that largely determine the international environment within the region (Naumkin, Baranovskiy, et al., 2018).

Some political analysts study the possibility of reorganizing the political space in WANA by using the world historical experience of international relations. It has become quite popular to look for global (but essentially European) historical analogues of the current situation in the region. C. Sazak (2016) and L. Kamel (2016), on the one hand, and B. Simms, M. Axworthy and P. Milton (2016), on the other, argue about a possible "Westphalian system for the Middle East" after the end of a "new Thirty Years' War." Earlier, Russian Ambassador Pyotr Stegny followed the same logic by contraposing the Westphalian format for the Middle East to the Versailles system (Stegny, 2012), which suggested comparing the current situation not with the Thirty Years' War, but with World War One. The authors of more practical works turn to the experience of the Helsinki agreement (Ivanov, 2016); the Arms Control and Regional Security Working Group, established 
in 1992 on the Moscow-based platform for multilateral Middle East settlement (Makhmutov and Mamedov, 2017); ASEAN (Mahbubani, 2017); or the African Union (Harrison, 2016).

A third possible approach that needs to be taken into account studies the situation in the region through the lens of the so-called 'alternative globalization' and prospects for the Islamic world's sovereignty in international relations. Among the various works addressing these issues, some recent ones deserve special mention: The Idea of the Muslim World. A Global Intellectual History (Aydin, 2017), and articles written by Russian researchers: V. Naumkin (2008), V. Baranovsky (2017), L. Fituni and I. Abramova (2018).

I will return to their ideas in the sections below, but first it is necessary to determine the key points to be considered:

1. The new world order, which has become a popular topic for discussion recently, is an international political projection of what in other spheres of social life and public conscience is referred to as neo-modernity.

2. The Middle East concept, understood as a distinct political region, is one of the "big narratives" in the era of modernity. Its initial ideological content suggested a certain type of political behavior for international actors, a specific subsystem of regional relations and specific regional identity.

3. The Islamic world concept based on pre-modern ideology can be regarded as an alternative to the Middle East concept.

4. In the era of post-modernity, the Middle East concept has begun to erode, while the idea of the Islamic world has come back into play.

5. In the era of neo-modernity, international relations in WANA will fluctuate between the Middle East model and the Islamic world model.

\section{NEO-MODERNITY IN LIEU OF A NEW WORLD ORDER}

Although fierce academic debates over the notions of 'world order' and 'system of international relations', their definition, boundaries and correlations continue in international relations (Dunaev, 2013), the general meaning of the word combination 'world order' is more 
or less clear. In this article I will use the definition proposed by Russian expert A. Nikitin, who defined it as "a relatively stable and rather sustainable condition, although limited in historical time, of the international system characterized by the prevalence of the rules of conduct in the international arena, recognized by the majority of actors (both state and non-state) and based on the balance of power and interests of leading world nations and political forces" (Nikitin, 2018, p. 32).

First expressed in international studies in the early 1990s essentially after the collapse of the bipolar system of relations, views have become quite widespread recently that the world order is in crisis and critically unstable, and that the efficiency of international institutions is declining and losing public trust (Lapkin, 2018, p. 37; Haass, 2014; Alekseenkova, 2015). Discussions, which never stopped over the past two decades, flared up with new intensity after the crisis in Ukraine in 2014, which, in Moscow's opinion, marked a watershed in relations between Russia and the West. The Russian political and academic communities spoke loudly about the emergence of a new world order, thus naturally raising the question of periodization.

Either the world entered a completely new period of development in 2014, which means that there existed some kind of specific (apparently unipolar) world order before that (1991-2014), or it did not, and in this case the current situation should be viewed as a new stage of processes that were set in motion in the 1990s (A. Nikitin (2018) and V. Baranovsky (2017) favor the latter approach, while V. Lapkin (2018), R. Haas (2008), J. Nye (2015), and many other authors uphold the former). Both points of view have many supporters and opponents, and their disputes are not always academic. Essentially, this is a clash between two completely different political concepts, each suggesting the formation of an intellectual basis for foreign policy strategies developed by different actors. One approach quite popular in Russia, in which a catastrophic view of the situation (Barabanov, Bordachev, et al., 2018) goes hand in hand with efforts to build a multipolar (or polycentric) world (Baranovskyy, 2017, p. 75), is in fact just one of the possible political programs. 
This logic suggests that the very acknowledgement of a crisis may be considered not as the result of an unbiased analysis of relatively objective reality, but as the expression of a changed self-perception by actors-observers. Moscow, Beijing, Tehran, and others speak about a crisis because they are seeking to reevaluate their own role in world politics, and in so doing they are creating this crisis, or so status quo proponents claim.

At the same time, such a constructivist approach must not be absolutized. For all the importance of subjective factors, the world disorder is obviously caused by certain objective elements of reality, such as economic growth in Asian countries, the emergence of a new technological mode, the crisis of the nation-state model created as part of European political culture, etc. Therefore, on the one hand, overcoming this crisis would obviously require a compromise between several global political projects and, on the other, efforts to adapt international political reality to the new socioeconomic and technological conditions.

The situation is compounded by several factors: firstly, by the fact that the final composition of key players who will be writing the new "rules of the game" is not determined and may not be determined ever; secondly, by the fact that not all of the self-proclaimed "architects" of a new world order are ready to propose their own world order concepts; and thirdly, by the fact that the technological transition is still in progress and its global socioeconomic effects have not manifested themselves in full yet.

All this creates uncertainty not only about the general outline of the future world order, but also the very possibility of building it. In this case, conglomeration theories of the modern world described by A. Bogaturov (2018) gain more points.

A key problem is that any author who tries to describe the contours of a new world order must not just be confident that it is possible, but also has to rely on existing models of organization from previous periods. This explains the secondary nature of all constructs that fail to take into account the fundamental dissimilarity of new historical conditions.

However, one can look at this issue from a broader angel than solely through the lens of international relations. 
If one considers international relations as one of the spheres of social life shaped by public conscience, it would be quite legitimate to correlate world order discussions with reflections on other spheres of social development.

The image of the world after "the end of history" has been explored in other humane studies in parallel with speculation about dramatic changes in world politics, albeit slightly faster.

More than twenty years ago J. Baudrillard said that "the Year 2000 would not take place. It would not take place simply because this century's history has already ended and we are in the process of constantly reliving it" (Baudrillard, 2008). Commenting on the blurring lines between the present and the future, and essentially on the abolition of both and their replacement with simulacra, the philosopher spoke about the emergence of the era of "postmodernity," which is organically unable to say anything new about itself and requires constant replaying. But these musings at the end of the 20th century did not usher in the era of postmodernity, for it had been creeping up from different directions for several decades (Leslie Fielder's Cross the Border - Close the Gap appeared in 1968 (published in 1969), and Jean-François Lyotard's The Postmodern Condition, in 1979), but rather registered its transition to the final stage where postmodernity turned from a state of an intellectual's mind and culture into a public and political routine-often an unconscious mode of thinking in society, which prescribes a certain way of political behavior.

The 21st century has brought along a series of speculations about a postmodern world. In 2002, Canadian scholar Linda Hutcheon announced the end of postmodernism: "The postmodern moment has passed, even if its discursive strategies and its ideological critique continue to live" (Hutcheon, 2002, p. 181). Shortly thereafter critical theory, art and literary criticism were flooded with all kinds of modernisms, such as postmodernism, automodernism (Samuels, 2008), digimodernism (Kirby, 2009), altermodernism (Bourriaud, 2009), transmodernism (Dussel, 2012), metamodernism (Vermeulen and van der Akker, 2010), etc. The concept of neo-modernity we are referring to in this article is among them. 
While differing in detail and focusing on different aspects of modernity, all these theories nevertheless have something in common.

Even their names clearly show that their authors describe the contemporary period in relation to the era of modernity, thus turning themselves into captives of history and voluntarily rejecting the freedom of defining a completely new state of being. They always understand modernity as the overcoming of postmodernism and at the same time as its development. Born out of postmodern mentality, these theories study the world after the end of history, thus rejecting its predetermined teleological course and, therefore, consider its return to postmodernity impossible (which is particularly evident in the theory of metamodernity (Vermeulen and van der Akker, 2010, p.5)). And yet, all of them appear to be quite serious and seek new meanings, while showing some frustration from an omnipresent postmodernist irony, which makes the search for responses to new challenges virtually impossible. This seriousness stems from the realization of a completely new economic, technological and informational state of the modern world. Globalization for these authors is not an abstract project, but a fait accompli. This explains the rejection of Eurocentrism, the emergence of new spatial perception, N. Bourriaud's idea of "cultural nomadism," and civilizational and cultural pluralism characteristic of postmodernity, which should eventually lead to the acceptance of Shmuel Eisenstadt's concept of multiple modernities (Eisenstadt, 2000).

Unlike other concepts, neo-modernity focuses on the analysis of political rather than aesthetic aspects and places emphasis on four key points which have already manifested themselves quite vividly in the political practices of several states in various parts of the world (Kuznetsov, 2017), but have been less analyzed in relation to international affairs (Kortunov, 2017).

First, the search for a new message and attempts to build new grand narratives, which completely lack trust.

Second, admitting fundamental instability and the transitional state of the new world, which may not and should not be overcome. 
Third, an appeal to the entire historical experience, instrumentalization of history, and broad use of premodern, archaic practices in search of a new narrative.

And fourth, the inevitable use of postmodern instruments (irony, skepticism, play), while formulating a new message.

If these four points are extrapolated to the aforementioned views concerning a new world order, one can identify several of its key features in light of neo-modernity.

1. A new world order, whatever it is, should be mobile, flexible, least formalized and a priori unstable.

2. The composition of actors forming it cannot be clearly defined, and the actors themselves will be mobile and heterogeneous, with multiple identities characteristic of each of them predetermining the difficulty in forming their political strategies and the plurality of foreign policy narratives.

3. The narrative, the need for a proper world order, and striving for some sort of stability will once again become important for all players. This should lead to the reemergence of ideology and a partial rejection of pragmatism for the sake of values, relative as they are. In some instances, this may cause pragmatism per se to turn into a self-sufficient value.

4. The objective blurring of lines, including those between domestic and foreign policies, and their growing interconnection will continue and become intertwined with attempts to strengthen the sovereignty of certain players as well as attempts at isolationism.

5. Such mobility and instability coupled with each actor's efforts to strengthen its own identities will generate greater anxiety and, therefore, greater securitization of international relations. The search for a common set of challenges and threats, which could provide the basis for positive interaction, will become central despite the differences in narratives and ideologies.

The WANA space will likely be drawn into this omnipresent world of neo-modernity, but its place in this world, its self-identity and manifestations of new trends in it need to be studied separately. 
"The transitional" nature and instability of the new state presumably manifests itself primarily in the coexistence within WANA of at least two regional/civilizational political identities engendered by different times and suggesting completely different models of political behavior.

The first is Middle Eastern identity.

\section{WANA AS THE MIDDLE EAST}

As V. Baranovsky and V. Naumkin have rightfully pointed out, "the emergence of a regional Middle Eastern identity became a key factor of the regional mega trend in the 20th century, namely, the formation of the Middle East as a single political region" (Naumkin, Baranovsky, 2018 , p. 36). The authors elaborate on this thought further to show that colonialism and the anti-colonial struggle caused WANA, initially divided into at least four sub-regions, to become what we now know as the modern Middle East.

Since colonialism and the national liberation movement it sparked in Middle Eastern countries were modern phenomena and the products of European Enlightenment (hence their ideological content), the Middle Eastern region can also be regarded as the product of modernity.

Emerging as a kind of political unity in the middle of the 20th century when most Arab countries were gaining independence, the appearance of the Middle East was driven, firstly, by Arab nationalism, which had proclaimed the unity of all Arab countries; secondly, by the creation of Israel, the struggle with which at the initial stage became an important incentive for consolidating Arabs and strengthening their common identity; and thirdly, by the anti-colonial aspirations of the newly independent states. Throughout subsequent decades, the borders of the region expanded to incorporate minor Arab Gulf states at first as its essential elements, which had gained independence slightly later than others, then Iran, which had rejected the Western way of development, and eventually Turkey, which had turned its eyes to the South. Finally, it incorporated Israel, even though initially it had antagonized its neighbors. 
As a political region, the Middle East has a rather clear-cut inner structure. It has an obvious center (Iraq, Syria, and Egypt), periphery (Maghreb), and frontiers (Mauritania, Sudan). The weakening of the regional core and the strengthening of the flanks (Turkey, Iran, and Saudi Arabia) were perhaps the main reasons for reformatting the Middle East in the 21st century.

The peculiarities of the region's formation determined the architecture of international relations that developed in the Middle East at that time. In addition, it was also in a way the product of modernity.

First of all, it bore (and still does) a clear imprint of postcolonialism. This feature became particularly manifest in the Middle East's dependence on non-regional actors, which had always ensured regional security (at first colonial powers and then the United States and the Soviet Union, and eventually only the United States) and the region's constant appeal for those actors' support in pursuing its own foreign policies. It is noteworthy that the success of Russia's operation in Syria and the inconsistency of the American policy conducted in the Middle East by the Obama and Trump administrations, obviously has led, among other things, to closer relations between Moscow and Riyadh (Katz, 2018), on the one hand, and between Moscow and Doha (Qatar-Russia, 2018), on the other, even though both Arab monarchies were extremely critical of Russia when it started its operation in Syria (Lucas, 2015, p. 5-6). The Saudi elites' fear of Iran and Qatar's desire to strengthen its own security in the face of the Saudi threat have forced them to look for new actors outside of the region, which potentially would be able to play a military role in regional affairs.

Another important feature of the Middle Eastern subsystem is that states became key elements of its organization, albeit carried out in a quite modernistic way.

Although formally claiming the status of nation-states, Middle Eastern countries have always been institutionally weak. As a result, the system they were building, which outwardly sought to copy the European experience with its powerful states and historical spatial organization, could never be implemented fully. As a result, state-centrism was replaced with regime-centrism and strong personalities, whereby the 
actual sovereign actors of this subsystem were political regimes often represented by concrete leaders. This is partly reminiscent of Europe in the 19th century with its concert of powers. Personalism has had a direct impact on regional relations. The tough stance assumed by Arab leaders with regard to Muammar al-Gaddafi was largely provoked by their personal dislike for the founder of the Third International Theory (Slackman, 2011), while a personal conflict between Saudi Crown Prince Mohammad bin Salman and the emir of Qatar is believed to be one of the main reasons for the Qatar crisis (Ramesh, 2017). At the same time, the institutional weakness of Middle Eastern states has prevented the formation not only of powerful supranational structures, but also of more or less efficient interstate political organizations that could have taken reginal cooperation to a new level.

The latter circumstance underscores the importance of nationbuilding in the region and the development of strong national (panArab, sub-regional or national) historical narratives which theoretically should assert the idea of national sovereignty of individual states. This explains the significant role of symbolic policy in Middle Eastern international relations (Zvyagelskaya, 2019) and competition between historical narratives in the regional powers' foreign policies.

This circumstance and attempts to build "big narratives" generate exclusivism, inherent in the Middle Eastern subsystem, when its countries ally against one of the regional states. This tactic has always been a cornerstone of relations in the region. Although different countries became pariah states at different times-Israel, Iraq, and most recently Iran - the existence of a pariah state has always been a sine qua non for regional consolidation. Interestingly, the desire to rally against Iran is the main motif for the revival of Arab nationalism today (Bin Saqir, 2016).

The abovementioned characteristics also explain why competition between powers for leadership in the region was and remains the main driver of development. This competition has several facets: firstly, there is no obvious leader, although there are more than enough aspirants; secondly, each of the contenders is relatively weak, which makes it quite sensitive to any interference in its internal affairs threatening the stability 
of the political regime, and forces it to constantly seek the support of external players; thirdly, the composition of contenders for leadership, which are quite fragile inside, keeps changing, thus making it impossible to create a durable regional concert. Each of the states considered to be regional pillars today-Turkey, Iran, Israel, Saudi Arabia, and Egypthas serious limits to its regional influence and is facing growing risks to political and socioeconomic stability. In addition, they have to look at "second tier" states, which by and large also nurture leadership ambitions - the United Arab Emirates, Qatar, and potentially Iraq.

On the whole, the Middle East is a region that embodies the modernistic model of international relations. The region uses the practices characteristic of the era of modernity, when anarchic principles of regional relations were combined with strongly pronounced pragmatism and realism in the foreign policy behavior of key actors, coupled with their value-oriented foreign policy strategies. When Nasser's Egypt or Ba'athist regimes supported friendly Arab nationalist movements, Iran helped Shiite minorities and political organizations in the region, Saudi Arabia assisted Salafi communities and organizations, and Qatar and Turkey backed the Muslim Brotherhood. All of these regimes reproduced the practices employed by the Soviet Union when it sponsored communist movements, and by the West when it promoted and advanced democracy. Notwithstanding all contradictions between realism and idealism in foreign policy, both without a doubt are characteristic of modernistic projects.

Although the Middle Eastern region occupies quite a prominent place in the system of international relations, its modernistic concept has been eroding lately.

In the 21st century, WANA's inner structure and borders have begun to crumble. The former tendency manifested itself in the aforementioned crisis in the core states (the conflict in Iraq and Syria, the political and economic crisis in Egypt) and before that in the actual abolition of the exclusivist model and the growing lack of consolidation between key actors in the region. None of the presentday lines of confrontation in WANA can bring the majority of regional players together to oppose any one country. Moreover, each of the 
existing alliances is not only situational, but also sectoral. In fact, while strongly opposing Tehran's military-political policy, the United Arab Emirates views Iran as an important economic partner.

The blurring of borders in the region has manifested itself in the Greater Middle East concept and in the strengthening of transregional cooperation (for example, Maghreb-EU). In fact, the latter is often more effective than intra-regional cooperation (the failure of the Arab Maghreb Union) in some parts of the Middle East.

In addition, the system of security outsourcing has waned. The United States alone can no longer maintain the fragile regional balance of power. Its invasion of Iraq failed to produce the desired results and turned the country into a source of new threats, causing exorbitant financial and reputational losses. Barack Obama's speech in Cairo in 2009, which Tel Aviv branded anti-Israeli, Washington's unwillingness to support the friendly Hosni Mubarak regime in 2011 and attempts to build a closer relationship with Iran were blasted by the White House's allies (Israel, Egypt under Abdel Fattah al-Sisi, and Saudi Arabia) as betrayal.

Donald Trump's endless intrigue around the recognition of Jerusalem as the capital of Israel and the upcoming "deal of the century," coupled with the new anti-Iranian policy, rejection of the JCPOA, and downright transactionalism with regard to Riyadh and Doha, have not made things any better.

And yet, no other non-regional actor, including Russia, is prepared to replace the United States in this part of the world.

All of these and some other developments (Kuznetsov, 2017) are proof of the Middle East's transition into a state of post-modernity where all features of its modernistic organization have been called into question. In fact, the region itself, while formally continuing to exist, is slowly losing its key characteristics, turning into what one American analyst described as a failed region.

\section{WANA AS PART OF THE ISLAMIC WORLD}

As the modernistic Middle East concept was waning, its alternative, essentially pre-modern, which regarded WANA as part of the Islamic world, began to gain momentum. 
Works devoted to a new world order, especially those exploring prospects for building a polycentric world, often mention the possibility of forming an Islamic center of global politics. Although their authors describe the Islamic world as a source of threats, note its lack of international sovereignty and expose its numerous inner contradictions (Naumkin, 2008, p. 485), they seem to recognize its potential for consolidation. This idea has been put forth not only by S. Huntington, who has been repeatedly and severely criticized by orientalists, but also by his opponents, including Russian scholars. For example, V. Baranovsky, while saying that the Islamic world's inner fragmentation "along country, clan and confessional lines turn 'a clash of civilizations' into a metaphor that can hardly be suitable for describing the system of international relations either in the global or regional context" (Baranovsky, 2017, p. 77), nevertheless puts it among possible centers of influence.

One of the latest Russian works on this subject is a paper written by L. Fituni and I. Abramova, who attempt to find signs of an emerging "Islamic center" in the global economy (Fituni and Abramova, 2018).

Any author who addresses the issue of the Islamic center in world politics faces a problem. The problem is that the medieval idea of the Islamic world (Dar al-Islam) hardly fits into the European modernistic concepts of the world order where the key elements are states, regional structures or non-state actors, but not civilizational communities.

Throughout the 20th century attempts were made, both in WANA and beyond, to modernize the Dar al-Islam concept. The biggest push led to the creation in 1969 of the Organization of the Islamic Conference (renamed in 2011 as the Organization of Islamic Cooperation), which has become the world's second largest intergovernmental organization after the United Nations, with a membership of 57 countries. While less conspicuous, prior attempts to lend international sovereignty to Islam were undertaken by some Islamic movements such as the Muslim Brotherhood, which tried to combine the idea of Islamic ummah with European concepts of nationalism in their ideology and practical work. Another was Pakistan's founder Muhammad Ali Jinnah, the author of the "two nations" theory. All these undertakings clearly 
indicated that Muslim intellectuals chose to appeal to confessional identity in the international practice. But they could not overcome the fundamental contradiction between the current development of the system of international relations and medieval theoretical constructs. This became quite obvious when Islamic economic institutions failed to occupy a dominant position even in Muslim countries.

At the same time, one cannot help noticing that the premodern perception of the Islamic world persisted and attempts to interpret reality through the prism of this perception never ended in a certain milieu.

The underlying idea was that the Ottoman Empire and earlier Arab Muslim states were not just religious countries, but they identified themselves by religion. Formally, they did not call themselves states, but Dar al-Islam. So hypothetically, the caliph's power extended not so much to a concrete territory, but to all the Muslims of the world. In traditional Islamic political theory, the territory of Islam has always been opposed to the Dar al-Kharb, the territory of war (that is, the territory to which the power of Islam should apply) and the Dar alSulh, the territory of treaty (that is, territories where Muslims do not have political superiority, but can freely profess their faith).

In the 21st century, hitherto marginal religious and political interpretations of international relations in WANA have begun to gain popularity, partly making their way into political practices and partly finding theoretical substantiation.

In the political practice, there are at least three manifestations of this: Daesh, al-Qaeda, and other jihadist and non-jihadist network Islamic organizations; the use of religious discourse for the consolidation of regional actors against common threats ("Sunni coalition," essentially Shiite axis of resistance, etc.); and the strengthening of extraterritorial confessional identity in Muslim communities beyond the Islamic world proper.

In the theoretical field, active efforts have been taken recently to explore certain issues in Islamic political theology, including the so-called Islamic jihad theology. Fierce debates between different theological schools, which provided conceptual and legal support 
for jihadist organizations, above all al-Qaeda and Daesh (Gasymov, 2015; Bunzel, 2015), generated incentives, as strong as the objectivelyformed new sociopolitical conditions, for the loyal ulama in various parts of the world to engage in the intellectual quest.

Undoubtedly, it is an important sign of the times that this intellectual quest has in recent years transcended the boundaries of the religious intellectual community and has become an element for broader interpretations of international processes in WANA. The very idea of analyzing regional processes through the lens of confessionalism, such as the confrontation between Shiites and Sunnis or between Muslims and Western "crusaders," as well as appeals for support of certain confessional groups by regional and non-regional actors has nothing to do with the modernistic understanding of international relations and has been generated by their Islamic conduct.

The gradual strengthening of the premodern Islamic world concept perforce raises the question of specific features of the world order characteristic of the relevant approach.

There are at least five key features, each of which can, of course, be interpreted differently.

The first is the fundamental unity of the world and the need for human laws to conform to divine law. This entails the principled rejection of the anarchic organization of international relations and requires everyone to abide by God's design and moral principles of life.

The second one is the superiority of heavenly things over worldly things, the supremacy of value-based politics, and the perception of international relations as relations between different confessional groups or, according to S. Qutb, between Islam and jahiliyya (barbarism), which become the main actors.

The third is binary confrontation between the world of faith and the world of unfaith (Dar al-Kufr) (Baranovsky and Naumkin, 2018), a conflict which may allow for compromise, but only temporarily, and rejection of secularism as the middle way between atheism and religiousness.

The fourth is the eschatological confidence in the ultimate victory of the world of faith over the world of unfaith. 
And lastly, the belief not in the territorial, but the network organization of the world order. The world of faith and the world of unfaith are not geographical objects, but rather human communities, one of which follows God's path, while the other one worships idols.

It must be stressed that all of the abovementioned specific features of the Islamic understanding of the world order are cited here in their radical form to highlight more vividly their conceptual core.

Although this perception is unlikely to be realized in WANA in full, some of its elements manifest themselves one way or another and often quite graphically.

For example, the extraterritorial organization of the ummah and the superiority of heavenly things over the worldly are upheld quite explicitly not only by the activities of Islamic parties and movements (the notorious Daesh "franchising" and the network organization of al-Qaeda and partly of the Muslim Brotherhood), but also by the demonstration of Islamic solidarity when confronted with common threats (especially at the symbolic level), as well as mutual support for Shiite minorities in the region (for example, Hezbollah and Yemeni Hussites), etc.

The eschatological vision of the world, in turn, makes it possible for Islamic parties to pursue a flexible policy, accept democratic practices and create temporary alliances with non-regional players, which, in light of the binary opposition of the world of faith to the world of unfaith, generate suspicions about the Islamists' "duel discourse."

\section{CONCLUSION}

A variety of principles of international relations are manifest in the emerging world of neo-modernity. While the Middle East concept within WANA is struggling with the challenges of postmodern relativism and some of its elements are waning, the premodern concept of the Islamic world, on the contrary, is regaining relevancy.

These two projects will most likely coexist in the world of neomodernity, even though some of their key parameters contradict each other. The table below schematically shows the main lines of confrontation. 
It is this ambivalence, which rules out a single and uncontroversial regional subsystem of relations, that will become the main feature of the new century.

\begin{tabular}{|l|l|l|}
\hline \multicolumn{2}{|c|}{$\begin{array}{c}\text { WANA between the Middle East and the Islamic world } \\
\text { in the era of neo-modernity. Lines of confrontation }\end{array}$} \\
\hline \multicolumn{1}{|c|}{ Neo-modernity } & \multicolumn{1}{|c|}{ Middle East } & \multicolumn{1}{c|}{ Islamic world } \\
\hline $\begin{array}{l}\text { A priory instability of the } \\
\text { world order }\end{array}$ & Anarchic principle & Unity of the world \\
\hline Heterogeneity of actors & Nation-states & Confessional groups \\
\hline Importance of narratives & National narratives & Religious narratives \\
\hline $\begin{array}{l}\text { Blurring of borders in search } \\
\text { of sovereignty }\end{array}$ & $\begin{array}{l}\text { Rigid regional architecture } \\
\text { and struggle for leadership }\end{array}$ & Extraterritoriality \\
\hline
\end{tabular}

\section{References}

Alekseenkova, E., 2015. Khaos i igra bez pravil: o sovremennom krizise doveriya $\mathrm{v}$ otnosheniyakh Rossii i Zapada. [Chaos and game without rules: on the current crisis of confidence in Russia-West relations]. Politija. Analiz. Hronika. Prognoz, No. 1, pp. 67 - 81.

Axworthy, M. and Milton, P., 2016. A Westphalian peace for the Middle East. Foreign Affairs [online]. Available at: https://www.foreignaffairs.com/articles/ europe/2016-10-10/westphalian-peace-middle-east?fbclid=IwAR3F61jVm 485HGTWymw65jdbY4OG5w-QUrAO0X1LpF_bWW4AtcyyWpz2D3A [Accessed 1 February 2019].

Aydin, C., 2017. The idea of the Muslim World. A global intellectual history. Harvard University Press, $304 \mathrm{p}$.

Barabanov, O., Bordachev, T., Lisovolik, Y., Lukyanov, F., Sushentsov, A., and Timofeev, I., 2018. Living in a Crumbling World. Valdai Club Annual Report, October 2018. [online] Available at: http://valdaiclub.com/a/reports/living-ina-crumbling-world/ [Accessed 5 February 2019].

Baranovsky, V., 2017. Transformatsia global'nogo miroporyadka: dinamika sistemnykh izmeneniy. [Transformation of global order: dynamics of systemic changes]. Polis. Politicheskie issledovaniya, 3 [online]. Available at: https://doi. org/10.17976/jpps/2017.03.05 [Accessed 9 February 2019]. 
Baranovsky, V. and Naumkin V., 2018. "Mir very" i "mir neveriya”: ekspansia i reduktsia religioznosti. [The world of belief and the world of disbelief: expansion and reduction of religiosity]. Polis. Politicheskie issledovaniya, 6, pp. 8-31.

Baudrillard, J., 1998. V teni tysacheletiya, ili priostanovka goda 2000. [In the shadow of the millennium, or the suspense of the year 2000]. [online]. Available at: http://filosof.historic.ru/books/item/f00/s00/z0000326/ [Accessed 16 February 2019].

Bin Saqer, Abd al-Aziz bin Usman, 2016. Al-Khalij fi 'am 2014-2015. Al-Ittihad al-khalijiy al-'arabiy huwa-l-mustaqbal. Qadaya al-aman wa-l-difa' fi duwal almajlis al-ta'aun al-khalidjiy. [Gulf in the year 2014-2015. The union of the Arab Gulf is the future. Security and defense issues in GCC]. Jeddah, Markaz alkhalidjiy li-l-abhath. Available at: http://www.grc.net/data/contents/uploads/ Dr_Sager_paper_3507.pd

Bogaturov, A., 2018. Sistemnoe i konglomerativnoe videnie sovremennogo mira. [Systemic and conglamerative vision of the contemporary world]. In: Sovremennaya politicheskaya nauka. Metodologiya. Moscow: Aspect-Press, pp. 9-610.

Bourriaud, N., 2009. Altermodern: Tate Triennial. Tate publishing.

Bunzel, C., 2015. From paper state to Caliphate: the ideology of the Islamic State. In: The Brookings Project on U.S. Relations with the Islamic World. Analysis Paper, No. 19.

Dunaev, A., 2013. Poniatiya 'Sistema' i 'poriadok' v istoriografii mezhdunarodnykh otnosheniy: trudnosti interpretatsii. [The notions of 'system' and 'order' in historiography of international relations: challenges of conceptual interpretation]. Vestnik Moskovskogo Universiteta, Series 25. Mezhdunarodnye otnoshenija i mirovaja politika, 2, pp. 4-22.

Dussel, E.D., 2012. Transmodernity and interculturality: an interpretation from the perspective of philosophy of liberation. Transmodernity: Journal of Peripheral Cultural Production of the Luso-Hispanic World, 1(3), pp. 28-55.

Eisenstadt, S. N., 2000. Multiple modernities. Daedalus, Vol. 129, No 1, pp. $1-29$.

Fituni, L.L. and Abramova, I.O, 2018. Musul'mansky polyus mirovoi ekonomiki i Dzhin globalizatsii [Muslim pole of the world economy and the Genie of globalization]. Vestnik MGIMO-Universiteta, 4(61), pp. 55-77.

Gantman, V., et al., 1984. Sistema, struktura i protsess razvitiya mezhdunarodnykh otnosheniy. [The system, structure and development process of international relations]. Moscow: Nauka. 
Gasymov, K., 2015. Razlad v stane dzhikhadistov: ideologicheskaya bor'ba al'-Kaidy s organizatsiey Islamskoe gosudarstvo [Discord in jihadists' camp: ideological fight between al-Qaida and ISIS]. Indeks bezopasnosti, No. 3(114), pp. 61-82.

Haas, R., 2014. The unraveling: how to respond to a disordered world. Foreign Affairs, 93 (6), pp. 70 - 79.

Haass, R., 2008. The age of nonpolarity. What will follow U.S. dominance? Foreign Affairs, May/June [online]. Available at: http://www.cfr.org/unitedstates/age-nonpolarity/p16034) [Accessed 5 February 2019].

Harrison, R., 2016.Toward a regional framework for the Middle East. Takeaways from other regions. MEI Policy [online]. Available at: https://www.mei.edu/ sites/default/files/publications/PP10_Harrison_RCS_regionalframework_ web_1.pdf [Accessed 15 February 2019].

Hutcheon, L., 2002. The politics of postmodernism. New York/London: Routledge.

Ivanov, I., 2016. Tri korziny dlia Blizhnego Vostoka ["Three baskets" for the Middle East]. Nezavisimaya gazeta [online] Available at: http://www.ng.ru/ dipkurer/2016-02-01/9_korziny.html [Accessed 15 February 2019].

Kamel, L., 2019. There is no Thirty Years' War in the Middle East. National Interest [online]. Available at: http://nation-alinterest.org/feature/there-nothirty-years-war-the-middle-east-17513 [Accessed 10 February 2019].

Katz, M., 2018. Balancing Act: Russia between Iran and Saudi Arabia. Middle East Centre Blog [online]. Available at: https://blogs.lse.ac.uk/mec/2018/06/26/ balancing-act-russia-between-iran-and-saudi-arabia/ [Accessed 7 May 2018].

Kirby, A., 2009. Digymodernism. How new technologies dismantle the postmodern and reconfigure our culture. London: Continuum.

Kortunov, A.V., 2017. From Post-Modernism to Neo-Modernism. Russia in Global Affairs, 1 [online]. Available at: https://eng.globalaffairs.ru/number/ From-Post-Modernism-to-Neo-Modernism-18578 [Accessed 15 January 2019].

Kosolapov, N., 2005. Rossiya: territoriya v prostranstvakh globaliziruyushchegosia mira [Russia: territory in the spaces of the globalizing world]. Mirovaya ekonomika i mezhdunarodnye otnosheniya, 7, pp. 3-14.

Kuznetsov, V., 2017. Posle postmoderna: blizhnevostochnoe izmerenie odnogo trenda [After postmodernism: Middle Eastern dimension of one trend]. Vostok. Afro-aziatskie obshchestva: istoriya i sovremennost', 3, pp. 25 - 37. 
Lapkin, V., 2018. O natsional'nom vs imperskom obustroistve sovremennogo miroporiadka. [Nation vs empire in the modern world order]. Polis. Politicheskie issledovaniya, 4, [online]. Available at: https://doi.org/10.17976/jpps/2018.04.04 [Accessed 9 February 2019].

Lucas, S., 2015. The effects of Russian intervention in the Syria crisis. Birmingham, UK: GSDRC, University of Birmingham.

Mahbubani, K., 2017. How the ASEAN "Miracle" is a model for the Middle East. Asia Society [online]. Available at: https://asiasociety.org/blog/asia/howasean-miracle-model-middle-east [Accessed 11 February 2019].

Makhmutov, T. and Mamedov, R., 2017. Predlozheniya k formirovaniyu sistemy regional'noi bezopasnosti v Zapadnoi Azii i Severnoi Afrike. [Proposals on the formation of new regional security system in Western Asia and North Africa]. Rossijsky sovet po mezhdunarodnym delam, 38. Moscow: RSMD.

Naumkin, V., 2008. Islam kak kollektivny igrok? [Islam as a collective actor?]. In: Islam i musul'mane: kul'tura i politika (stat'i, ocherki i doklady raznykh let). Moskva-N. Novgorod: Medina, pp. 483-502.

Naumkin, V., Baranovskiy, V., et al., 2018. Blizhny Vostok v meniayushchemsia global'nom kontekste [The Middle East in the changing global context]. Moscow: IV RAN.

Nikitin, A., 2018. Sovremenny miroporadok: yego krizis i perspektivy. [Modern world order, its crisis and prospects]. Polis. Politicheskie issledovaniya, 6 [online]. Available at: https://doi.org/10.17976/jpps/2018.06.03 [Accessed 9 February 2019].

Nye, J.S. Jr., 2015. Is the American century over? Cambridge, Malden: Polity Press.

Qatar-Russia relations touch new heights. The Peninsula [online]. Available at: https://thepeninsulaqatar.com/article/02/08/2018/Qatar-Russia-relationstouch-new-heights [Accessed: 2 January 2019].

Ramesh, R., 2017. The long-running family rivalries behind the Qatar crisis. The Guardian [online] Available at: https://www.theguardian.com/ world/2017/jul/21/qatar-crisis-may-be-rooted-in-old-family-rivalries [Accessed 15 February 2019].

Samuels, R., 2008. Auto-modernity after postmodernism: autonomy and automation in culture, technology, and education. In: Tara McPherson (ed.) Digital Youth, Innovation, and the Unexpected. Cambridge, MA: The MIT Press. Doi: 10.1162/dmal.9780262633598.219 
Sazak, C.S., 2016. No Westphalia for the Middle East. Foreign Affairs [online]. Available at: https://www.foreignaffairs.com/articles/middle-east/2016-10-27/ no-westphalia-middle-east?fbclid=IwAR0CqSLEdwyYxL13orlVbP71PECF3jv yBRNJRrRUZvQZXaAzGTiq64uLm7s [Accessed 7 February 2019].

Simms, B., Axworthy, M. and Milton, P., 2016. Ending the new Thirty Years War. NewStatesman [online]. Available at: http://www.newstatesman.com/ politics/uk/2016/01/ending-new-thirty-years-war [Accessed 1 February 2019].

Slackman, M., 2011. Arab leaders' dislike for Qaddafi creates unity. The New York Times [online]. Available at: <https://www.nytimes.com/2011/03/22/ world/africa/22arab.html> [Accessed 5 March 2019].

Stegny, P., 2012. The Middle East: a'la Versailles or a'la Westphalia? Russia in Global Affairs, No. 4 [online]. Available at: https://eng.globalaffairs.ru/ number/The-Middle-East--la-Versailles-or--la-Westphalia-15822 [Accessed 15 February 2019].

Vermeulen, T. and van der Akker, R., 2010. Notes on Metamodernism. Journal of Aesthetics \& Culture, Vol. 2. DOI: 10.3402/jac.v2i0.5677.

Voskresensky, A., 2012. Konceptsii regionalizatsii, regional'nykh podsistem, regionalnykh kompleksov i regionalnykh transformatsy $\mathrm{v}$ sovremennykh mezhdunarodnykh otnosheniyakh [The concepts of regionalization, regional subsystems and regional transformations in modern international relations]. Sravnitelnaja politika, 2 (8), pp. 30 - 58.

Zvyagelskaya I. and Kuznetsov, V., 2017. Gosudarstvennost' na Blizhnem Vostoke. Budushcheye nachalos' vchera. [Statehood in the Middle East. The future that started yesterday]. Mezhdunarodnye protsessy, 15 (4), pp. 6-19.

Zvyagelskaya, I., 2018. Blizhny Vostok i Tsentral'naya Aziya: Global'nye trendy $v$ regional'nom ispolnenii. [The Middle East and Central Asia. Global trends in regional implementation]. Moscow: Aspect-Press, 224 pp.

Zvyagelskaya,I.D.,2019. Simvolyitsennostiv mezhdunarodnykhotnosheniyakh na Blizhnem Vostoke. [Symbols and values in international relations in the Middle East]. Polis. Politicheskie issledovaniya. No.1, pp. 105-123. Available at: https://doi.org/10.17976/jpps/2019.01.08 